\title{
HISTOLOGICAL ANALYSIS OF INDIRECT SOMATIC EMBRYOGENESIS INDUCED FROM ROOT EXPLATS OF OIL PALM (Elaeis guineensis Jacq)
}

\author{
Marlucia Souza Pádua Vilela ${ }^{\oplus}$, Jessica de Castro e Andrade ${ }^{3} \odot$, Raissa Silveira Santos ${ }^{4} \odot$, Vanessa Cristina

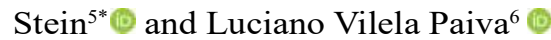

\footnotetext{
${ }^{1}$ Received on 29.01.2018 accepted for publication on 17.04.2019.

${ }^{2}$ Universidade Federal de Lavras, Doutora em Biotecnologia, Lavras, MG- Brasil. E-mail: <marluciabio@yahoo.com.br>.

${ }^{3}$ Universidade Federal de Lavras, Mestre em Biotecnologia Vegetal, Lavras, MG- Brasil. E-mail: <jessicanep andrade@hotmail.com>.

${ }^{4}$ Universidade Federal de Lavras, Programa de Pós-Graduação em Agronomia, Lavras, MG- Brasil. E-mail: <raissa_silveira93@hotmail.com>.

${ }^{5}$ Universidade Federal de São João Del-Rei, Campus Centro-Oeste, Divinópolis, MG- Brasil. E-mail: <vanessastein@ufsj.edu.br>.

${ }^{6}$ Universidade Federal de Lavras, Departamento de Química, Lavras, MG- Brasil. E-mail: <luciano@dqi.ufla.br>.

*Corresponding author.
}

\begin{abstract}
Oil palm is economically important as a crop with high oil production. Indirect somatic embryogenesis in oil palm requires a long time for callus induction and plant formation, and it is important to study the embryogenic potential of calli and the mechanisms of somatic embryogenesis. The aim of this study was to test different growth regulators and spermine in induction of embryogenic calli in root explants of oil palm (Elaeis guineensis Jacq). Apex root explants of approximately $0.5 \mathrm{~cm}$ were isolated from plants cultivated in vitro and inoculated in $\mathrm{Y} 3$ culture medium in the following treatments: A - without growth regulators; $\mathrm{B}-1$ mg. $\mathrm{L}^{-1}$ picloram (4-amino-3,5,6-trichloro-2-pyridinecarboxylic acid); $\mathrm{C}-1 \mathrm{mg} . \mathrm{L}^{-1}$ picloram and $2 \mathrm{mg} . \mathrm{L}^{-1} 2 \mathrm{ip}$ (2-isopentenyladenine); D - $2 \mathrm{mg} . \mathrm{L}^{-1}$ 2ip; $\mathrm{E}-1 \mathrm{mg} . \mathrm{L}^{-1}$ picloram and $2 \mathrm{mg} . \mathrm{L}^{-1}$ BAP (6-benzylaminopurine); F - 2 mg. $\mathrm{L}^{-1}$ BAP; and $\mathrm{G}-14.5 \mathrm{mg} . \mathrm{L}^{-1}$ spermine. After six months of culturing, the calli induced in the treatments were analyzed by light microscopy. The calli induced in the treatments with $1 \mathrm{mg} \cdot \mathrm{L}^{-1}$ picloram (B) and treatment with $14.5 \mathrm{mg} . \mathrm{L}^{-1}$ spermine $(\mathrm{G})$ exhibited embryogenic characteristics, small and isodiametric cells, forming agglomerates, besides a large amount of starch. Calli of the best treatment (Y3 com $1 \mathrm{mg} . \mathrm{L}^{-1} \mathrm{de}$ picloram) were inoculated in Y3 culture medium without addition of growth regulators. After eight months, calli were once more analyzed under light microscopy. All the treatments showed callus formation, except for treatments D and A. Calli of treatment B exhibited cells with embryogenic characteristics that developed somatic embryos.
\end{abstract}

Keywords: Elaeis guineensis, plant tissue culture, callus.

\section{ANALISES HISTOLÓGICAS DA EMBRIOGÊNESE SOMATICA INDIRETA A PARTIR DE EXPLANTES RADICULARES DE DENDEZEIRO}

\begin{abstract}
RESUMO - O dendezeiro é economicamente importante pela alta produção de óleo. A embriogênese somática indireta em dendezeiro demanda longo tempo de indução de calos e formação das plantas, sendo importante o estudo do potencial embriogênico dos calos e os mecanismos da embriogênese somática. Oobjetivo deste estudo foi verificar o efeito de diferentes reguladores de crescimento e espermina na indução de calos embriogênico em explantes de raizes de dendezeiro. Explantes apicais radiculares de aproximadamente $0,5 \mathrm{~cm}$ foram isolados de plantas cultivadas in vitro e inoculadas em meio de cultura Y3 com os seguintes tratamentos: meio A - sem reguladores de crescimento; $B$ - $1 \mathrm{mg} . \mathrm{L}^{-1}$ picloram (ácido 4-amino-3,5,6-tricloro-2-piridinacarboxílico); $C$ - 1 mg. $L^{-1}$ de picloram e $2 \mathrm{mg} . \mathrm{L}^{-1}$ de 2ip (2-isopenteniladenina); $D$ - $2 \mathrm{mg} \cdot \mathrm{L}^{-1}$ de 2ip; $E$ - $1 \mathrm{mg} . \mathrm{L}^{-1}$ de picloram e 2 $m g . L^{-1}$ de BAP (6-benzilaminopurina); $F-2 m g . L^{-1}$ de BAP; e $G-14,5 m g . L^{-1}$ de espermina. Após, seis meses de cultivo, foram realizadas analises histológicas. Os calos induzidos nos tratamentos com $1 \mathrm{mg} . L^{-1}$ picloram (B) e 14,5 mg.L $L^{-1}$ espermina (G) apresentaram características embriogênicas, células pequenas, isodiamétricas e formando aglomerados, apesar da grande quantidade de amido. Os calos do melhor tratamento (Y3 com 1
\end{abstract}

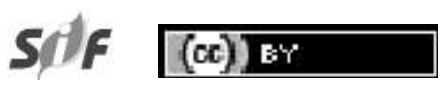

Revista Árvore 2019;43(1):e430106 http://dx.doi.org/10.1590/1806-90882019000100006 
mg. $L^{-1}$ de picloram) foram inoculados em meio de cultura de $Y 3$ sem adição de reguladores de crescimento para sua regeneração, que após oito meses foram realizadas novas análises histológicas. Todos os tratamentos apresentaram formação de calo, com exceção dos tratamentos $D$ e A. Os calos do tratamento B exibiram células com características embriogênicas, que desenvolveram embriões somáticos.

Palavras-Chave: Elaeis guineensis, Cultura de Tecidos Vegetais, Calos.

\section{INTRODUCTION}

Oil palm stands out among oilseeds through the large quantity and good quality of oil produced by its bunches in comparison with other oilseeds, for example, soybean, which produces approximately $400 \mathrm{~kg}$ per hectare, whereas oil palm produces approximately $6,000 \mathrm{~kg}$ per hectare, with low production cost (Agrianual, 2012). The oil from oil palm is widely used in the food, cosmetics, and pharmaceutical industries and for production of biofuels (Mya et al., 2010).

Due to wide use of oil palm, it is important to expand crop area; however, seedlings are scarce on a commercial scale because of limitation of having a single apical meristem per plant, which makes propagation by conventional methods such as cuttings impossible. Thus, the seeds are the main propagation method, and they may have dormancy, leading to slow germination (three years) at low percentages (30\%) (Luis, 2010).

An alternative for seedling production on a commercial scale that is becoming more prominent for palm species is tissue culture through somatic embryogenesis. During the somatic embryogenesis process, growth regulators are necessary for dedifferentiation during callus formation and differentiation for formation of somatic embryos. Picloram stands out among these growth regulators used to callus induction in palm (Steinmacher et al., 2007; Moura et al., 2008; Pádua et al., 2013; Mazri et al., 2018). The association of auxins with cytokines an also favor callus formation, as observed in Paspalum vaginatum Flüggé (Neibaur and Altpeter, 2008) and Elaeis guineensis Jacq (Silva et al., 2009; Balzon, 2013).

Polyamines have been studied in the induction of embryogenic calli; of wich prutecine, spermine and spermidine are the most commonly reported for this use (Aydin et al., 2016). Putrescine was successful in callus induction in oil palm (Rajesh et al., 2003). Polyamines act in a manner similar to growth regulators, with the advantage of promoting DNA stability and, consequently, normal growth (Galston and Sawhney, 1990, Bae et al., 2018).

In addition to the growth regulator, another important factor in obtaining somatic embryogenesis is the explant used. For oil palm, many studies cite the use of explants from leaves (Pádua et al., 2013), zygotic embryos (Balzon, 2013), and inflorescences (Steinmacher-Pereira et al., 2010). There are few reports regarding explants from Elaeis guineensis Jacq roots; however, roots are an explant alternative and may be used for propagation of plants transformed with Agrobacterium rhizogenes Riker.

In this context, for success in indirect somatic embryogenesis, identification and characterization of calli with embryogenesis potential is of crucial importance. The calli can be characterized according to morphological and cytological aspects by means of cytochemical analyses according to the modified Leica ${ }^{\circledR}$ historesin protocol. This technique allows the embryogenic calli to be distinguished from the nonembryogenic calli, and allows greater understanding of cell development and morphogenesis (Pádua et al., 2013).

Cytochemical analyses through the use of stains such as Lugol's iodine allow visualization of embryogenic characteristics, like the presence of starch, which is an indicator de embryogenic competence in oil palm (Silva et al., 2014). Small isodiametric cells with large nuclei and prominent nucleoli, mitochondria, cytoplasm with little intercellular space, and a cell system organized in cells with embryogenic potential can be visualized through toluidine blue stain. Non-embryogenic calli mostly have large, elongated, and vacuolated cells, with intercellular spaces and a disorganized cell system, and they are not viable (Pádua et al., 2013; Gomes et al., 2016).

\section{Revista Árvore 2019;43(1):e430106}


The aim of this study was to evaluate the effect of both spermine and a combination of growth regulators on somatic embryogenesis using explants from oil palm roots.

\section{MATERIALS AND METHODS}

\subsection{PLANT MATERIAL}

The Denpasa Company of Pará, Brazil provided immature fruit of Elaeis guineensis Jacq of the Manicoré hybrid at approximately 100 days after pollination.

\subsection{DISINFESTATION AND OBTAINING SEEDLINGS}

Oil palm fruits were first washed in sodium hypochlorite $(1.25 \%)$ and then opened to remove the exocarp, mesocarp, and endocarp, exposing the endosperms. The endosperms were washed in running water and placed in a laminar flow chamber for disinfestation. They were then immersed in $70 \%$ alcohol for $30 \mathrm{~s}$ followed by sodium hypochlorite

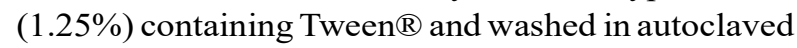
distilled water three times for five min under constant shaking. The embryos were isolated from the endosperms and inoculated in Petri dishes containing modified Y3 culture medium (Eeuwens, 1978), supplemented with 45 g.L-1 of sucrose and $0.6 \%$ (w/v) agar, and $\mathrm{pH}$ was adjusted to $5.7 \pm 0.1$.

After inoculation, the embryos were exposed to a 16-h photoperiod at a temperature of $26 \pm 2{ }^{\circ} \mathrm{C}$. After that, they were transferred to magenta vessels containing the same culture medium, where they were subcultured every 30 days.

\subsection{CALLOGENESIS}

Roots of the seedlings obtained in vitro after 7 months of culturing were used for callus induction. The apex/meristem root explants of approximately $0.5 \mathrm{~cm}$ length were inoculated in Y3 culture medium (Eeuwens, 1978), supplemented with different growth regulators. The media used for treatments were as follows: A - without growth regulators;

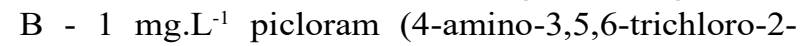
pyridinecarboxylic acid); $\mathrm{C}-1 \mathrm{mg} \cdot \mathrm{L}^{-1}$ picloram and $2 \mathrm{mg} . \mathrm{L}^{-1}$ 2ip (2-isopentenyladenine); $\mathrm{D}-2$ mg. $\mathrm{L}^{-1}$ 2ip; $\mathrm{E}-1$ mg. $\mathrm{L}^{-1}$ picloram and $2 \mathrm{mg} . \mathrm{L}^{-1}$
BAP (6-benzylaminopurine); F - $2 \mathrm{mg} . \mathrm{L}^{-1}$ BAP; and $\mathrm{G}-14.5 \mathrm{mg} . \mathrm{L}^{-1}$ spermine. The experiment was conducted in a completely randomized design with 100 replicates per treatment.

Culture mediums were supplemented with 30 g. $\mathrm{L}^{-1}$ sucrose, solidified with $6 \mathrm{~g} . \mathrm{L}^{-1}$ agar and the $\mathrm{pH}$ adjusted to $5.7 \pm 0.1$. After inoculation, the explants were kept in a growth room under dark conditions and temperature of $27 \pm 2^{\circ} \mathrm{C}$. After 3 months of inoculation, the percentage of callus formation in each culture medium was evaluated, and cytochemical analyses of the calli were performed.

\subsection{INDUCTION OF SOMATIC EMBRYOS}

The embryogenic calli of the Y3 treatment supplemented with $1 \mathrm{mg} . \mathrm{L}^{-1}$ picloram were transferred to Y3 culture medium (Eeuwens, 1978) without addition of growth regulators and with 1 g.L. $\mathrm{L}^{-1}$ of activated carbon for conversion into somatic embryos.

Culture mediums were supplemented with 30 g.L $\mathrm{L}^{-1}$ sucrose and solidified with 6 g. $\mathrm{L}^{-1}$ agar, and $\mathrm{pH}$ was adjusted to $5.7 \pm 0.1$. This material was kept in a growth room exposed to a photoperiod of $16 \mathrm{~h}$ at a temperature of $27 \pm 2^{\circ} \mathrm{C}$.

After eight months of culturing, the embryos obtained were collected for histochemical analyses.

\subsection{CYTOCHEMICAL AND HISTOCHEMICAL ANALYSES}

The samples (calli and somatic embryos) were fixed in FAA (formalin, acetic acid, and 70\% alcohol) for $72 \mathrm{~h}$ and conserved in $70 \%$ ethanol. After that, they were dehydrated in ethylic series, infiltrated in alcohol + resin $(50 \%)$ overnight, then in pure resin for $48 \mathrm{~h}$, and finally embedded in Leica resin according to manufacturer's protocol. The samples were sectioned at a thickness of $5 \mu \mathrm{min}$ a rotary microtome and stained with $0.05 \%$ toluidine blue and weak Lugol's iodine solution; they were then set up on slides and viewed in a Zeiss Scope.A1 light microscope coupled to a camera.

\section{RESULTS}

Callus formation in roots explants was observed in all the culture media supplemented with growth regulators, except for culture medium $\mathrm{D}$, supplemented 
with $2 \mathrm{mg} . \mathrm{L}^{-1}$ of 2iP. Moreover, culture medium B, supplemented with $1 \mathrm{mg} . \mathrm{L}^{-1}$ picloram, exhibited the highest percentages of callus induction (33\%) (Fig.1).

The calli induced in the culture media exhibited embryogenic characteristics, with the exception of calli induced in the culture medium supplemented with 2 mg. $\mathrm{L}^{-1}$ BAP (treatment G). Calli induced in the culture medium supplemented with $1 \mathrm{mg}$. $\mathrm{L}^{-1}$ picloram exhibited isodiametric cells in division that formed clusters and contained starch (Fig. 1 A,B, and C). Association of the growth regulator picloram (1 $\left.\mathrm{mg} . \mathrm{L}^{-1}\right)$ with BAP $\left(2 \mathrm{mg} . \mathrm{L}^{-1}\right)$ induced the formation of calli with small isodiametric cells with evident nuclei, which formed clusters and contained starch, though in smaller quantity than the calli obtained in the other treatments with 2 mg.L ${ }^{-1}$ BAP (Fig. 1 D, E, and F).

The calli induced in culture media containing BAP exhibited regions with embryogenic cells, characterized by small isodiametric cells with nuclei, as well as regions with large, irregular, and dispersed cells, non-embryogenic characteristics. The calli of this treatment had a larger number of cells with nonembryogenic characteristics compared to the calli of the other treatments with $1 \mathrm{mg} . \mathrm{L}^{-1}$ picloram and 2 mg.L. ${ }^{-1}$ BAP (Fig. 2 G, H, and I). The calli cells obtained in the Y3 culture medium supplemented with $1 \mathrm{mg} . \mathrm{L}^{-1}$ picloram and $2 \mathrm{mg} . \mathrm{L}^{-1} 2 \mathrm{ip}$ had small isodiametric cells in division, with evident nuclei and starch in surrounding cells (Fig. $2 \mathrm{~J}, \mathrm{~K}$, and L). In the culture medium supplemented with $14.5 \mathrm{mg}$. $\mathrm{L}^{-1}$ spermine, the calli had small isodiametric cells with evident nuclei, forming clusters in the shape of a whirl, with dispersed surrounding cells (Fig. $2 \mathrm{M}, \mathrm{N}$, and $\mathrm{O})$.

The calli of the treatment containing $1 \mathrm{mg} . \mathrm{L}^{-1}$ picloram were subcultured, and after six months of culturing, they gave rise to somatic embryos and were collected for cytochemical analyses.

In somatic embryos at the torpedo stage, the presence of the three primary meristems (procambium, fundamental meristem, and protoderm) were observed in sections stained with toluidine blue. The histochemical analyses with Lugol's iodine stain, evidenced a large amount of starch around of embryo tissue (Fig. 3).

This study showed the beginning of formation of these procambium (Pc), fundamental meristem (Fm) and protoderm (Pt) meristemsin embryos differentiated on $\mathrm{Y} 3$ culture medium with $1 \mathrm{mg} . \mathrm{L}^{-1}$ picloram (Fig. 3).

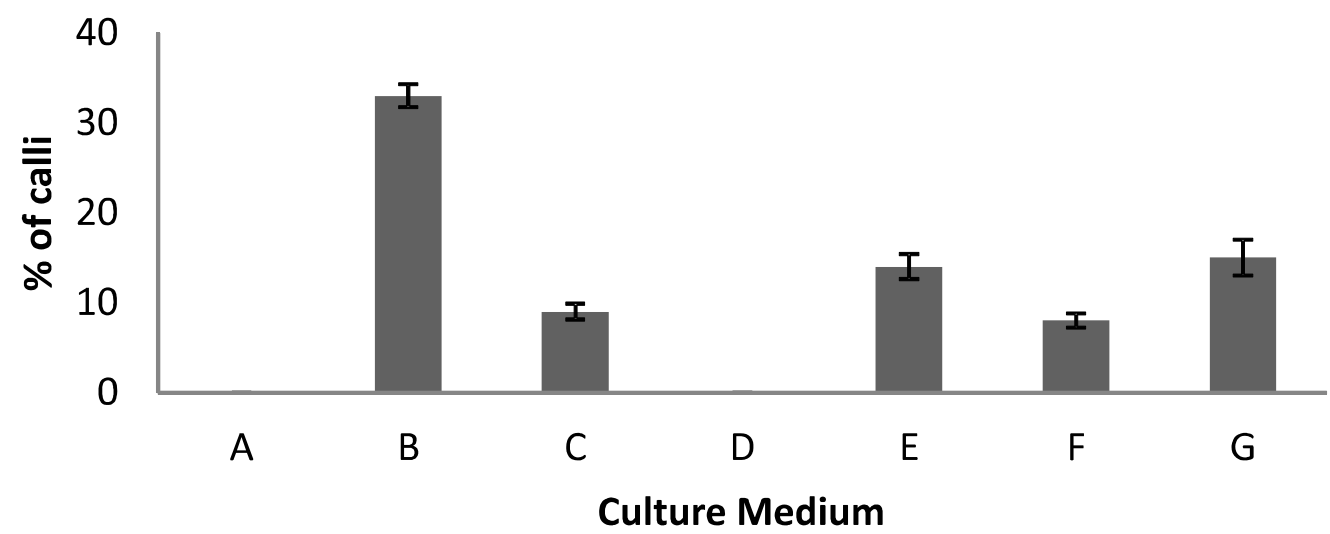

Figure 1 - Percentage of callus induction in Elaeis guineensis Jacq. root explants. A - Y3 culture medium without addition of growth regulators, B - Y3 culture medium supplemented with $1 \mathrm{mg} . \mathrm{L}^{-1}$ picloram, C - Y3 culture medium supplemented with 1 mg. $\mathrm{L}^{-1}$ picloram and $2 \mathrm{mg} . \mathrm{L}^{-1}$ of $2 \mathrm{iP}, \mathrm{D}-\mathrm{Y} 3$ supplemented with $2 \mathrm{mg} . \mathrm{L}^{-1}$ of $2 \mathrm{iP}, \mathrm{E}-\mathrm{Y} 3$ supplemented with $1 \mathrm{mg} . \mathrm{L}^{-1}$ of picloram and 2 mg.L. $\mathrm{L}^{-1}$ of BAP, F-Y3 supplemented with $2 \mathrm{mg} . \mathrm{L}^{-1}$ of BAP, G-Y3 supplemented with $14.5 \mathrm{mg} . \mathrm{L}^{-1}$ of spermine.

Figura 1 - Porcentagem de indução de calos em explantes radiculares de Elaeis guineenses Jacq. Meio de cultura A - Y3 sem adição de reguladores de crescimento (controle), meio de cultura $B$ - Y3 suplementado com $1 \mathrm{mg} . \mathrm{L}^{-1}$ de picloram, meio de cultura $C$ - Y3 suplementado com $1 \mathrm{mg} . L^{-1}$ de picloram e $2 \mathrm{mg}$. $L^{-1}$ de $2 i P$, D- Y3 suplementado com $2 \mathrm{mg}$. $L^{-1}$ de $2 i P$, E- Y3 suplementado com 1mg. $L^{-1}$ de picloram e $2 \mathrm{mg}$. $L^{-1}$ de BAP, F - Y3 suplementado com $2 \mathrm{mg} \cdot L^{-1}$ de BAP, G- Y3 suplementado com $14.5 \mathrm{mg} . L^{-1}$ de espermina.

Revista Árvore 2019;43(1):e430106 


\section{DISCUSSION}

The highest percentages of callus formation were observed in the root explants in medium B with $1 \mathrm{mg} \cdot \mathrm{L}^{-1}$ picloram (33\%). This growth regulator was also efficient in callus induction in oil palm from other explants, such as zygotic embryos (Balzon et al., 2013), inflorescences (Scherwinski-Pereira et al., 2010) and leaves (Marbun et al., 2015).
The calli formed on root explants of the treatment containing $1 \mathrm{mg} . \mathrm{L}^{-1}$ picloram were subcultured, and after six months of culturing, they gave rise to somatic embryos. The culture medium containing the growth regulator picloram associated with $2 \mathrm{ip}$ in zygotic embryos of oil palm favored the proliferation and maintenance of embryogenic calli (Balzon et al., 2013). In macaúba, Acrocomia aculeata (Jacq.) Lodd. ex Mart., the induction of embryogenic masses using

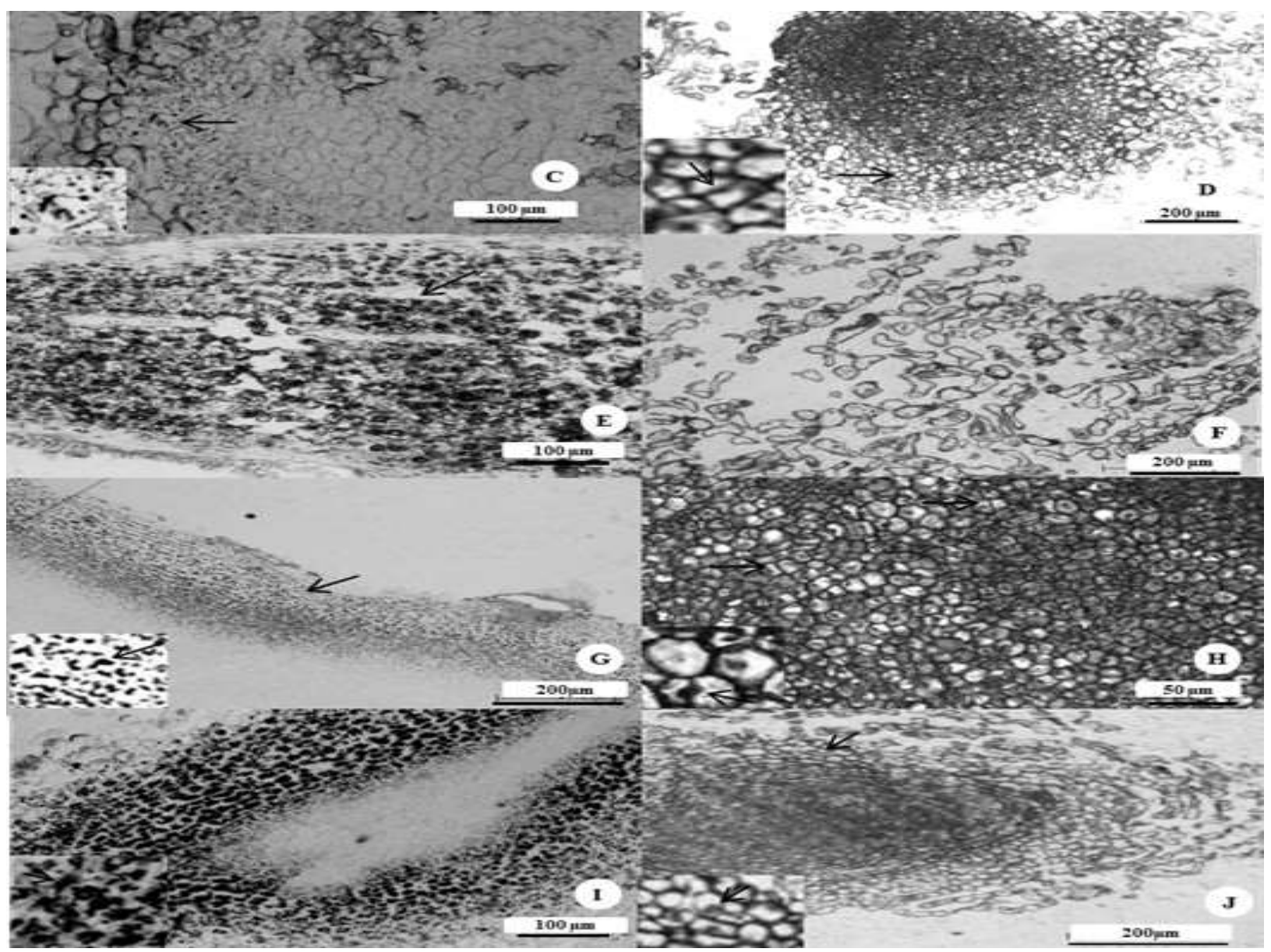

Figure 2 - Calli induced in root explants of the oil palm hybrid Manicoré. Calli induced in Y3 culture medium supplemented with 1 mg.L-1 picloram (A), stained with Lugol's iodine (B), and stained with toluidine blue (C). Calli induced in Y3 culture medium supplemented with $1 \mathrm{mg} . \mathrm{L}-1$ picloram supplemented with $2 \mathrm{mg} . \mathrm{L}-1$ BAP (D), stained with Lugol's iodine (E) and toluidine blue (F). Calli induced in Y3 culture medium supplemented with $2 \mathrm{mg}$.L-1 BAP $(\mathrm{G})$ stained with Lugol's iodine $(\mathrm{H})$ and toluidine blue (I). Calli induced in Y3 culture medium supplemented with $1 \mathrm{mg} . \mathrm{L}-1$ picloram and $2 \mathrm{mg} . \mathrm{L}-1$ 2iP (J) stained with Lugol's iodine $(\mathrm{K})$ and toluidine blue (L). Calli induced in Y3 culture medium supplemented with $1 \mathrm{mg} . \mathrm{L}-1$ picloram and $100 \mu \mathrm{M}$ spermine (M) stained with Lugol's iodine $(\mathrm{N})$ and toluidine blue $(\mathrm{O})$.

Figura 2 - Caloss induzidos em explantes radiculares de Elaeis guineensis Jacq. híbrido Manicoré. Calos induzidos em meio de cultura Y3 suplementado com $1 \mathrm{mg} . L-1$ de picloram (A), corado com Lugol (B) e corado com azul de toluidina (C). Calos induzidos em meio de cultura Y3 suplementado com $1 \mathrm{mg}$.L-1 de picloram suplementado com $2 \mathrm{mg} . L-1$ de BAP (D), corado com Lugol (E) e azul de toluidina $(F)$. Calos induzidos em meio de cultura Y3 suplementado com BAP $(G)$ com 2 mg.L-1 coradas com Lugol (H) e azul de toluidina (I). Calos induzidos em meio de cultura Y3 suplementado com $1 \mathrm{mg} . L-1$ de picloram e $2 \mathrm{mg}$.L-1 de 2iP (J) corados com Lugol (K) e azul de toluidina (L). Calos induzidos em meio de cultura Y3 suplementado com 1 mg.L-1 picloram e $100 \mu \mathrm{M}$ de espermina (M) coradas com Lugol (N) e azul de toluidina (O). 


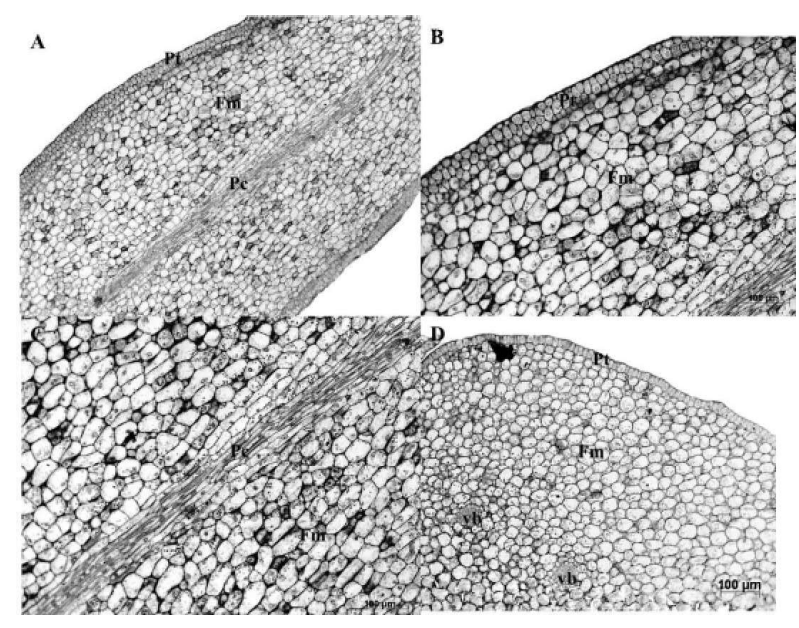

Figure 3 - Histochemistry of somatic embryos of the Elaeis guinenesis Jacq hybrid Manicoré induced from root explants in Y3 culture medium supplemented with 1 mg. $\mathrm{L}^{-1}$ picloram. A) Longitudinal sections of somatic embryos stained with toluidine blue show the presence of tissues of the procambium $(\mathrm{Pc})$, fundamental meristem $(\mathrm{Fm})$, and protoderm $(\mathrm{Pt})$. B) Protoderm and fundamental meristem. C) Procambium and fundamental meristem. D) Cross-section showing the vascular bundles (vb), fundamental meristem (Fm), and protoderm $(\mathrm{Pt})$.

Figura 3-Histoquímica dos embriões somáticos de Elaeis guineenses Jacq hibrido Manicoré induzidos de explantes radiculares em meio de cultura Y3 suplementado com 1 $m g . L^{-1}$ de picloram. A) seções longitudinais de embriões somáticos corados com azul de toluidina mostram a presença dos tecidos do procambium (Pc), meristema fundamental $(\mathrm{Fm})$ e protoderme $(\mathrm{Pt}), \mathrm{B})$ protoderme $e$ meristema fundamental, $C$ ) procambium e meristema fundamental, D) Seção transversal mostrando os feixes vasculares $(v b)$, meristema fundamental $(F m) e$ protodermo $(\mathrm{Pt})$.

picloram associated with $\mathrm{BAP}$ or $2 \mathrm{iP}$ also induced the formation of embryogenic masses (Padilha et al., 2015).

Calli with potential for forming somatic embryos are generally obtained from explants of young plant tissues, such as zygotic embryos, however they can also be obtained from stems, roots and leaves (Fehér et al., 2016). For Elaies guineensis Jacq, the mature embryos are the most used for plants regeneration (Thuzar et al., 2011; Balzon et al., 2013). However regeneration protocols from embryos cannot be used when clonal propagation is intended since we cannot predict the nature of the regenerants (Jayanthi et al., 2015). In date palm (Phoenix dactylifera cv. Medjool), embryogenic calli were successfully induced in root segments with silver nitrate and BAP (Roshanfekrrad et al., 2017). However, Guo et al. (2018) studied genes involved in callus induction from the root explants of Oryza sativa L. and Arabidopsis thaliana, suggesting that genes involved in callus induction pathways differ among species. Therefore, the present study is to develop an efficient method using in vitro roots as explants, with the lowest cost and time and the greatest potential to obtain oil palm Elaies guineensis Jacq in vitro plantlets and produce embryogenic callus and somatic embryos.

This study showed that introduction of spermine polyamine led to calli with embryogenic characteristics, though at low percentages (16\%). Rajesh et al. (2003) also observed similar percentages in callus induction in oil palm from embryos with spermine polyamine (15\% of the explants), and this is an alternative for callus production in oil palm (Rajesh et al., 2003).

Polyamines, especially putrescine, spermidine, and spermine, play a role in cell division and differentiation. Spermidine and spermine are associated with differentiation and putrescine with cell division. They also act as intracellular mediators of hormonal activity and are present in all plant cells (Steward et al., 1999), and in the literature on the use of plant protection products (Sequeramutiozabal et al., 2016). Polyamines participate in the somatic embryo formation pathway, and inhibit the synthesis of ethylene, which, in turn, is an inhibitor of embryogenesis and morphogenesis (Kumar et al., 2008; Faust and Wang, 2010; Aydin et al., 2016; El Dawayati, 2018).

The pathways of both polyamines and ethylene have S-adenosylmethionine (SAM) as a precursor, and competition for SAM may occur between these biosynthetic pathways, which explains the addition of polyamines to the culture medium to increase somatic embryogenesis (Minocha et al., 1999; El Dawati et al., 2018).

In addition, polyamines have been described as protecting DNA against damage caused by reactive oxygen species (ROS), giving stability to nucleic acids by binding to phosphate groups and, in particular, forming complexes with DNA. This linkage leads to stabilization of the nucleic acid structure or to changes in its conformation, and in control of DNA methylation (Ha et al., 1998; Hou et al., 2001; Brooks et al., 2010). 
For oil palm, maintaining genetic stability in micropropagated plants, by in vitro culture, in high concentrations of growth regulators, over long periods, is of great importance due to the characteristic somaclonal variation of the species, which may occur, called the mantled flower. Corrêa et al. (2016) used putrescine instead of cytokine for oil palm, and they observed high production capacity of embryogenic lines. They also noted shorter culture time, and this is an alternative to avoid possible variations in the DNA stability of plants produced in vitro. Embryogenic characteristics were also observed in oil palm calli obtained from leaf explants in the presence of the picloram auxin at different concentrations in the culture medium (Pádua et al., 2013). Embryogenic characteristics, such as evident nuclei and isodiametric cells arranged in clusters (Steinmacher et al., 2011) were observed in peach palm calli, obtained in a culture medium supplemented with picloram.

In the calli induced in the culture medium supplemented with $2 \mathrm{mg} . \mathrm{L}^{-1}$ de BAP, cells with opposing characteristics (elongated, dispersed and irregular cells) could be observed in analyses with toluidine blue stain (Fig. 1G, H, and I). From the shape of the cells, generally dispersed elongated cells, with large vacuoles are in an apoptosis process, that is, programmed cell death (Steiner et al., 2005).

The small rounded cells, arranged in clusters and with a nucleus strongly stained by toluidine blue, have embryogenic potential, confirmed in various studies from the differentiation of these cells, followed by formation of embryos and later germination into plants (Aslam et al., 2011; Ângelo et al., 2013).

The presence of cells arising from the periphery of globular structures, observed in Figure 1, was also viewed in somatic embryos of macaúba (Acrocomia aculeata (Jacq.) Lodd.ex Mart.) (Moura, 2008). These cells were described as a layer of stratified covering that surrounded the nodular structure of embryogenic calli of Eucalyptus globulus Labill (Corredoira et al., 2015). In this study, the introduction of spermine polyamine was favorable to induction of calli with embryogenic characteristics. Putrescine was used successfully on the calli introduction and somatic embryo induction and germination in oil palm explants (Rajesh et al., 2003). Starch was observed in the cells in all the treatments that induced calli. Storage of starch in the embryo and in embryogenic cells or in adjacent cells is a phenomenon that commonly indicates the acquisition of embryogenic competence (Moura, 2008), with starch grains being produced prior to the formation of somatic embryos to initiate and sustain their development. Histochemical analysis of the process of somatic embryogenesis in peach palm showed that starch accumulation generally precedes the development of somatic embryos (Steinmacher et al., 2011).

The study of somatic embryogenesis through histological observations has proved to be increasingly useful, encompassing the use of various techniques that allow the events that occur when plant species are cultivated in vitro to be detailed. In this way, for example, it is possible to know and monitor the cell and tissue development of plant material during the different stages of the process of somatic embryogenesis. Moreover, histological analyses make it possible to elucidate aspects related to the somaticembryogenic cell transition, which are rather unclear, especially in palm trees (Meira et al., 2019).

Calli induced in the culture medium supplemented with $1 \mathrm{mg} . \mathrm{L}^{-1}$ picloram exhibited isodiametric cells in division that formed clusters and were subcultured giving rise to somatic embryos, that at the torpedo stage presented three primary meristems (procambium, fundamental meristem, and protoderm). The protoderm, characterized by a layer of juxtaposed cells and prominent nucleus, is precursor meristem of the epidermis. The presence of protoderm is an indicator of somatic embryo formation (Aslam et al., 2011). The protoderm and procambium tissue were also observed during formation of somatic embryos in oil palm (Ângelo et al., 2013).

The formation of protoderm, fundamental meristem, and procambium occurs during the initial phases of development of the somatic embryos, however, can vary in sequence and time, according to culture conditions. For example, in macauba, the protoderm formation was observed in somatic embryos at the beginning of the globular stage (Moura, 2008) and in this work we observed the protoderm formation at the torpedo stage.

The cells of the fundamental meristem are larger and polyhedral and are followed by cells that have an elongated shape, in the central region of the embryo, characterizing as procabial cells, the precursor 
meristem of vascular tissues. The macaw palm (Acrocomia aculeata) somatic embryos also showed meristematic cells of different formats and sizes and no vascular connection with the callus of origin, which ratifies the somatic embryogenesis pathway (Meira et al., 2019).

Therefore, this work describes the development of somatic embryos of Elaeis guineensis Jacq from roots explant and the polyamine spermine effect on somatic embryo indiction, which has been little studied up to now in palm trees. Moreover, anatomical markers of embryogenic calli were described in this work, such as development of meristematic tissue during the somatic embryo formation. Such efficient method, using in vitro roots explants, allows the lowest cost and time to increase the potential to obtain oleic palm Elaeis guineensis Jacq in vitro plantlets by somatic embryos.

\section{CONCLUSION}

Normal somatic embryos of Elaeis guineensis Jacq were regenerated from roots explant calli in medium supplemented with $1 \mathrm{mg} . \mathrm{L}^{-1}$ picloram and histological analysis evidenced the primary meristematic tissues development during the somatic embryos formation.

\section{AKNOWLEDGMENTS}

We thank the Conselho Nacional de Desenvolvimento Científico e Tecnológico (CNPq), the Fundação de Amparo à Pesquisa de Minas Gerais (FAPEMIG) and the Coordenação de Aperfeiçoamento de Pessoal de Nível Superior (CAPES).

\section{REFERENCES}

Agrianual. Anuário da Agricultura Brasileira: Coco-da-baía. São Paulo: FNP, Consultoria e Agro informativos; 2012. p.285-91.

Ângelo PCS, Steinmacher DA, Lopes R, Cunha RNV, Guerra MP. Histological analysis and transcription profiles on somatic embryogenesis in interspecific hybrids of Elaeis guineenses x $E$. oleifera. Agricultural Sciences. 2013;4(11):1-11.

Aslam J, Khan SA, Cheruth AJ, Mujib A, Sharma MP, Srivastava PS. Somatic embryogenesis, scanning electron microscopy, histology and biochemical analysis at different developing stages of embryogenesis in six date palm (Phoenix dactylifera L.) cultivars. Saudi Journal of Biological Sciences. 2011;18(4):369-80.

Aydin M,Hossein Poura, Haliloglu K, Tosun M. Effect of polyamines on somatic embryogenesis via mature embryo in wheat. Turkish Journal of Biology. 2016; 40:1178-1184

Bae D-H, Lane DJR, Jansson PJ, Richardson DR. The old and new biochemistry of polyamines. Biochimica et Biophysica Acta. 2018;1862(9):2053-68.

Balzon TA, Luis ZG, Scherwinsk-Pereira JE. New approaches to improve the efficiency of somatic embryogenesis in oil palm (Elaei sguineensis Jacq.) from mature zygotic embryos. In Vitro Cellular \& Developmental Biology Plant. 2013;49(1):41-50.

Brooks WH, Le Dantec C, Pers JO, Youinou P, Renaudineau Y. Epigenetics and autoimmunity. Journal of Autoimmunity. 2010;34(3):207-19.

Corrêa T R, Motoike S Y, Andrade A P S, Coser S M, Queiroz V, Granja M M C, Caetano D D N, Peña C N M, Picoll E A T. Accelerated in vitro propagation of elite oil palm genotypes (Elaeis guineenses Jacq.) by substituting cytokinin with putrescine. African Journal of Biotechnology. 2016, 15(50):2817-2825.

Corredoira E, Ballester A, Ibarra M, Vieitez AM. Induction of somatic embryogenesis in explants of shoot cultures established from adult Eucalyptus globulus and E. saligna $x$ E. maidenii trees. Tree Physiology. 2015;35(6):678-90.

Eeuwens CJ. Mineral requirements for growth and callus initiation of tissue explants excised from mature coconut palms (Cocos nucifera) and cultured in vitro. Physiologia Plantarum. 1978;36(1):23-8.

El-Dawayati M M, Ghazzawy H S, Munir M. Somatic embryogenesis enhancement of date palm cultivar Sewi using diferente types of polyamines and glutamine amino acid concentration under in-vitro solid and liquid media conditions. International Journal of Biosciences. 2018. 12:1490159.

Faust M, Wang SY. Polyamines in horticulturally important plants. In: Janick J, editor. Horticultural Reviews, John Willy \& Sons, Inc. Canada. 2010.

\section{Revista Árvore 2019;43(1):e430106}


$14: 335-353$.

Galston AW, Sawhney RK. Polyamines in plant physiology. Plant Physiology. 1990;94(2):406-10.

Gomes HT, Bartos PMC, Balzon TA, ScherwinskiPereira JE. Regeneration of somatic embryos of oil palm (Elaeis guineensis) using temporary immersion bioreactors. Industrial Crops and Products. 2016;89:244-9

Ha HC, Sirisoma NS, Kuppusamy P, Zweier JL, Woster PM, Casero RA. The natural polyamine spermine functions directly as a free radical scavenger. Proceedings of the National Academy of Sciences USA. 1998;95:11140-45.

Hou MH, Lin SB, Yuann JM, Lin WC, Wang AH, Kan LS. Effects of polyamines on the thermal stability and formation kinetics of DNA duplexes with abnormal structure. Nucleic Acids Research. 2001;29(5):5121-8.

Kumar V, Giridhar P, Chandrashekar A, Ravishankar GA. Polyamines influence morphogenesis and caffeine biosynthesis in in-vitro cultures of Coffea canephora. Acta Physiologiae Plantarum. 2008: 30: 217-223.

Luis ZG, Bezerra KMG, Scherwinski-Pereira JE. Adaptability and leaf anatomical features in oil palm seedlings produced by embryo rescue and pre-germinated seeds. Brazilian Journal of Plant Physiology. 2010;22(3):209-15.

Marbun CLM, Toruan-Mathius N, Utomo RC, Liwang T. Micropropagation of embryogenic callus of oil palm (Elaeis guineenses Jacq.) using temporary immersion system. Procedia Chemistry. 2015;14:122-9.

Fehér A, Bernula D, Gémes K. The Many Ways of Somatic Embryo Initiation. In: Loyola-Vargas V, Ochoa-Alejo N, editors. Somatic embryogenesis: Fundamental aspects and applications. Springer: Springer International Publishing; 2016.p.297-318.

Meira FS, Luis ZG, Silva-Cardoso IA, ScherwinskiPereira JE. Developmental pathway of somatic embryogenesis from leaf tissues of macaw palm (Acrocomia aculeata) revealed by histological events. Flora. 2019;250:59-67.
Jayanthi M, Susanthi B, Murali Mohan N, Manda PK. In vitro somatic embryogenesis and plantlet regeneration from immature male inflorescence of adult Dura and Tenera palms of Elaeis guineensis (Jacq.) Springer Plus. 2015;4:256.

Mazri MA, Meziani R, Belkoura I, Mokhless B, Nour S. A combined pathway of organogenesis and somatic embryogenesis for an efficient large-scale propagation in date palm (Phoenix dactylifera L.) $\mathrm{cv}$. Mejhoul. 3 Biotech. 2018;8(4):215.

Minocha R, Smith DR, Reeves C, Steele KD, Minocha SC. Polyamine levels during the development of zygotic and somatic embryos of Pinus radiata. Physiologia Plantarum. 1999;105:15564.

Moura EF, Ventrella MC, Motoike SY, Sá Júnior AQ, Carvalho M, Manfio CE.. Histological study of somatic embryogenesis induction on zygotic embryos of macaw palm (Acrocomia aculeata (Jacq.) Lodd.Ex Martius). Plant Cell Tissue and Organ Culture. 2008;95(2):175-84.

Mya T, Vanavichit A, Tragoonrung S, Jantasuriyarat C. Efficient and rapid plant regeneration of oil palm zygotic embryos cv. 'Tenera' through somatic embryogenesis. Acta Physiologiae Plantarum. 2010;33(1):123-8

Neibaur I, Gallo M, Altpeter F. The effect of auxin type and cytokinin concentration on callus induction and plant regeneration frequency from immature inflorescence segments of seashore paspalum (Paspalum vaginatum Swartz). In Vitro Cellular \& Developmental Biology - Plant. 2008;44(6):480-6.

Padilha JHD, Ribas LLF, Amano E, Quoirin M. Somatic embryogenesis in Acrocomia aculeata Jacq. (Lodd.) ex Mart using the thin cell layer technique. Acta Botânica Brasílica. 2015;29(4):516-23.

Pádua MP, Paiva LV, Labory CRG, Alves E, Stein VC. Induction and characterization of oil palm (Elaeis guineensis Jacq.) pro-embryogenic masses. Anais da Academia Brasileira de Ciências. 2013;85(4):1545-56.

Rajesh MK, Radha E, Karun A, Parthasarathy VA. Plant regeneration from embryo-derived callus of oil palm - the effect of exogenous polyamines. Plant Cell Tissue and Organ Culture. 2003;75(1):41-7. 
Roshanfekrrad M, Zarghami R, Hassani H, Zakizadeh H, Salari A. Effect of AgNO3 and BAP on Root as a Novel Explant in Date Palm (Phoenix dactylifera cv. Medjool) Somatic Embryogenesis. Pakistan Journal Biological Sciences.

2017;20(1):20-7.

Scherwinski-Pereira JE, Guedes RS, Fermino Jr PCP, Silva TL, Costa FHS. Somatic embryogenesis and plant regeneration in oil palm using the thin cell layer technique. In Vitro Cellar \& Developmental Biolology - Plant. 2010; 46(4):378-85.

Sequeramutiozabal MI, Erban A, Kopka J, and Al E. Global metabolic profiling of Arabidopsis polyamine oxidase 4 (AtPAO4) loss-of-function mutants exhibiting delayed dark-induced senescence. Front. Plant Sci. 2016; 7:173.

Silva AS, Luz JMQ, Rodrigues TM, Marques SV, Marques RV, Pasqual M. Diferentes reguladores de crescimento na indução de calos e pró-embrióides em anteras de cafeeiro. Bioscience Journal. 2009;25(4):19-27.

Steiner N, Vieira FN, Maldonado S, Guerra MP.
Effect of carbon source on morphology and histodifferentiation of Araucaria angustifolia embryogenic cultures. Brazilian Archives of Biology and Technology. 2005;48(6):895-903.

Steinmacher DA, Guerra MP, Saare-Surminski K, Lieberei R.. A temporary immersion system improves in vitro regeneration of peach palm through secondary somatic embryogenesis. Annals of Botany. 2011;108:1463-75.

Steinmacher DA, Krohn NG, Dantas ACM, Stefenon VM, Clement CR, Guerra MP.. Somatic embryogenesis in peach palm using the thin cell layer technique: Induction, morpho-histological aspects and AFLP analysis of somaclonal variation. Annals of Botany. 2007;100(4):699-709.

Steward N, Martin R, Engasser JM, Goergen, JL. Plant Cell Reports. 1999; 19: 171.

Thuzar M, Vanavichit A, Tragoonrung S, Jantasuriyarat C. Efficient and rapid plant regeneration of oil palm zygotic embryos cv Tenera through somatic embryogenesis. Acta Physiologiae Plantarum. 2011,33(1):123-8 